\title{
A new editorial vision for the JAES
}

\author{
Patrick G. Eriksson ${ }^{\mathrm{a},}$ and Sospeter M. Muhongo ${ }^{\mathrm{b}}$,
}

a Department of Geology, University of Pretoria, Pretoria 0002, South Africa

b Regional Office for Africa, International Council for Science (ICSU), P.O. Box 13252, Hatfield, Pretoria, South Africa

\section{Article Outline}

1. Introduction

2. A new editorial vision for the JAES

3. A new focus for the JAES: core fields for potential manuscripts

4. The new JAES procedure once your paper is submitted electronically

5. A new editorial structure

6. Conclusion

\section{Introduction}

Elsevier have revised their manuscript-handling procedure for all Earth Sciences journals, including the Journal of African Earth Sciences (JAES), from the beginning of 2008. Previously, a professionally qualified member of Elsevier's staff received all newly submitted manuscripts and first previewed them for overall scientific quality, suitability for the specific journal, and quality of English, before rejecting some on these grounds, while others were sent to reviewers. All of these functions now devolve upon the relevant Editors-in-Chief of the Elsevier Earth Sciences journals, in the case of the JAES, upon Sospeter Muhongo and Pat Eriksson. This brings a much wider responsibility upon the two of us, but at the same time provides an opportunity to improve the quality of papers finally appearing in the journal.

Some changes, which may strike certain potential authors as somewhat radical, are thus now proposed with a view to greatly enhancing the status of the JAES. We are therefore taking the initial steps in early 2008 to ensure that we indeed reach the ultimate goal of making the journal the best and most respected outlet, globally, for the publication of excellent research dealing with African geology. Our efforts at raising the quality of papers as much as we can, across the board, will necessarily be a relatively gradual initiative: firstly, papers currently in the publication pipeline which were handled 
according to the previous system will be cleared, and secondly, new papers will gradually be subjected to the full effect of a new vision for the Journal of African Earth Sciences.

\section{A new editorial vision for the JAES}

While we fully recognize the unique difficulties under which many if not a majority of African and Middle Eastern geological scientists and authors labour, reflecting a past colonial history and other inequities as well as present realities, we also regard with pride the great progress that our Continent and region has made, in terms of democratization, economic improvements, social advances and scientific progress, encompassed in the vision of this being the beginning of the African Century. If we are to take our deserved place as equals within the global scientific community, it is essential that we apply the highest possible standards to editing the JAES to produce, with time, a journal that measures up fully to any other national or regional geoscientific journal across the globe. There is also an increasing number of national or more local geoscientific journals within Africa and the Middle East, whose quality and relevance are growing as our region advances in all endeavours. Instead of the JAES being in competition with these very worthy publications, we would greatly prefer to see ourselves as a partner linked to the overall advancement of African Earth Sciences. We thus see a very clear distinction between papers of local interest, which must logically be submitted to local or national African journals, and those of Pan-African or, preferentially even global impact, which should logically be submitted to the JAES. The same philosophy applies to highly specialized papers, which better belong within the pages of relevant highly focused international journals - examples of such papers would include highly technical papers dealing with detailed methodologies, particularly of the applied geological sciences, or with highly specialized topics of little interest to the general African, Middle Eastern and international geoscientist. The Journal of African Earth Sciences sees itself thus as a general geological journal, focused on a set of core geological disciplines, listed below, and aimed at a readership comprising essentially of professional company geologists, geological survey staff, small firm private practice earth science professionals, and academics. Manuscripts submitted to the JAES should thus preferably fall within the major focus areas listed below, be of at least a regional African scale or context (defined as encompassing at least several African countries), and appeal to an interested readership of African and international geologists with a wide rather than a highly specific range of geoscientific interests. In other words, local studies or highly specialized manuscripts, lacking wider implications and international appeal will not be sent out to review at all by JAES from 2008 onwards - these papers should be referred to local or specialist journals, as discussed earlier in this paragraph.

\section{A new focus for the JAES: core fields for potential manuscripts}

The new focus of the JAES will thus be on core geological disciplines, in addition to applied disciplines - accepted papers within the latter field are obviously still very 
welcome, but should encompass a strong link to core geological data and also be of broad (preferentially international) appeal rather than serving only a limited, specialized audience. The overall result of this new approach will almost certainly be a reduction in the number of papers published per year, initially, but this will be balanced by a significantly higher quality and appeal of published papers. In other words, it will become an achievement to publish a paper in the Journal of African Earth Sciences, not just for African and Middle Eastern researchers, but also for any international geoscientist. We wish to improve ourselves to become a respected and established global player.

We will thus set out to attract papers within five major categories (and will also rewrite the aims and scope of the journal accordingly), viz:

(1) African geodynamics: geochronology, tectonics, structural geology - of the African and Arabian plates, their cratons and mobile belts.

(2) African-Middle Eastern basin analysis: stratigraphy, sedimentology, palaeontology, palaeogeography, and sequence stratigraphy.

(3) Petrology: igneous and metamorphic petrology, mineralogy, geochemistry and isotope geology.

(4) Economic Geology: with the emphasis on major ore deposits, and commodities like hydrocarbons, and industrial minerals.

(5) Applied Geology: where this is directly related to core geological data or at least a minimum geological basis, and studies are of wide appeal.

The same basic philosophy will be applied to suggested special issues, which need to be discussed first with Sospeter and Pat before being submitted to Elsevier for approval. We thus must aim at becoming a really serious African journal devoted to the core geological disciplines and hard science.

\section{The new JAES procedure once your paper is submitted electronically}

Once you have uploaded your manuscript electronically via the relevant JAES weblink, pdf's of these papers are supplied to either Sospeter Muhongo or Pat Eriksson (authors indicate which of the two they feel is more au fait with the topic of their paper), who must take an initial decision along the following lines:

(a) Paper unsuitable: a paper that does not fit the scope of the JAES is considered unsuitable and will be recommended to be sent to a more suitable publication.

(b) Paper has "poor language": this is a paper where the English is too poor for it to be sent out to reviewers.

(c) Paper rejected: scientific quality is too low to send out to review.

(d) Paper "incorrect": the electronic submission is incomplete - e.g., figures missing, etc. 
If none of the above four cases apply, then the manuscript will be sent out to review, with reviewers being chosen by the relevant Editors-in-Chief or a suitable member of the associate editorial panel. Authors are encouraged, in their electronic submission, to provide a list of recommended reviewers - this is used, in addition to other referees, by the editors of the JAES.

\section{A new editorial structure}

In order to achieve the overall aim of radically enhancing the quality of JAES papers and the impact of the journal, it will be necessary to restructure the current editorial team of the Journal. Currently, there are two Editors-in-Chief (Muhongo and Eriksson) and an editorial advisory board of about 50 members. During 2008, and following detailed discussions with Elsevier Earth Sciences Management, a new JAES editorial structure will be defined. This will logically comprise three tiers:

(1) The Editors-in-Chief.

(2) Eleven Associate Editors, two to each defined core discipline (Geodynamics; Basin Analysis; Petrology; Economic Geology), with three under Applied Geology (Geophysics, Groundwater, Remote Sensing).

(3) An Editorial Advisory Board of about 15 members.

The roles of the Editors-in-Chief have already been defined above. The associate editors, being specialized within the various identified core geological disciplines, would with time be brought into the editorial process itself, being sent a certain number of papers by the Editors-in-Chief, which papers they would then see through the entire reviewing process, making a final recommendation to the Editors-in-Chief on acceptance of corrected papers. The role of the advisory board is to generate high quality papers for the journal, and to act as expert reviewers of highly regarded papers.

\section{Conclusion}

We feel strongly that it is necessary to adopt the new approach outlined in this editorial, for the good of the Journal of African Earth Sciences, and for the betterment of AfricanMiddle Eastern geoscientific endeavour as a whole. It is time that the African scientific community took its rightful place amongst its global geological peers, and the JAES, as the official publication of the Geological Society of Africa, sees its role as assisting this growth in all possible ways. We thus look forward, in time, to forming a new and dynamic partnership with the editorial team and our most important and respected clients, who are the authors and geoscientists of our African and Middle Eastern hinterland. 